\title{
Sustained Ventricular Tachycardia by ECG Finding
}

National Cancer Institute

\section{Source}

National Cancer Institute. Sustained Ventricular Tachycardia by ECG Finding. NCI

Thesaurus. Code C71052.

An electrocardiog raphic finding of ventricular tachycardia greater than 30 seconds in duration. 